Boise State University

ScholarWorks

Biology Faculty Publications and Presentations

Department of Biological Sciences

$1-1-1997$

\title{
Tribal Relationships in the Gesneriaceae: Evidence from DNA Sequences of the Chloroplast Gene $n d h \mathrm{~F}$
}

James F. Smith

Boise State University

J. C. Wolfram

Boise State University

K. D. Brown

Boise State University

Cynthia L. Carroll

Boise State University

D. S. Denton

Boise State University 


\section{TRIBAL RELATIONSHIPS IN THE GESNERIACEAE: EVIDENCE FROM DNA SEQUENCES OF THE CHLOROPLAST GENE $n d h \mathrm{~F}^{1}$}

\section{AbSTRACT}

The tribal relationships of the Gesneriaceae are investigated using $n d h \mathrm{~F}$ sequences. A full analysis of 70 taxa including 16 species from the Scrophulariaceae, Bignoniaceae, and Acanthaceae as outgroups, resulted in two mostparsimonious trees of 5610 steps each. In all trees the Gesneriaceae were a monophyletic group and Paulownia was the closest single-species outgroup for the analysis. Further analyses eliminated all but the members of the Gesneriaceae and Paulownia in order to better assess relationships within the family. The smaller analysis resulted in a single mostparsimonious tree of 4613 steps. The Klugieae are identified as the sister to the remainder of the family and could potentially be separated as a distinct subfamily. The subfamilies Cyrtandroideae (excluding Klugieae) and Gesnerioideae are monophyletic. The placement of Coronanthereae in Cyrtandroideae does not have support from this analysis, whereas its placement in Gesnerioideae is supported. Alternatively, Coronanthereae could be segregated as a separate subfamily but in order to avoid a paraphyletic Gesnerioideae would either include the Napeantheae and Beslerieae or elevate these two tribes to an additional subfamily. Within Gesnerioideae the genus Sinningia is removed from the tribe Gloxinieae into the Sinningieae, which also contains the recently combined species Sinningia brasiliensis (Lietzia), as well as Paliavana and Vanhouttea. The Episcieae, Gesnerieae, Napeantheae, and Beslerieae are identified as monophyletic groups, as are the remainder of the Gloxinieae with Sinningia sensu lato removed. Within Cyrtandroideae, several well-supported, monophyletic lineages within the large, heterogeneous tribe Didymocarpeae are identified, and with the current data the tribe Trichosporeae appears to be polyphyletic. The distribution of chromosome numbers, nodal anatomy, placental structure, and stem modification are examined based on these molecular trees.

Investigations of higher level cladistic relationships (generic, familial, and above) have recently drawn a great deal of attention (Annals of the Missouri Botanical Garden Vol. 80(3); Olmstead et al., 1992, 1993; Donoghue et al., 1992; Cantino, 1992; Judd et al., 1994). These analyses have provided tremendous insights toward our classification system and process of classification, frequently drawing attention to families that have been separated on the basis of primarily woody versus herbaceous taxa (Cantino, 1992; Judd et al., 1994) or tropical versus temperate (Judd et al., 1994). More recently an investigation of the Lamiales sensu lato has indicated that the largest family in this order, Scrophulariaceae, is unlikely to be a monophyletic group (Olmstead et al., 1992, 1993; Olmstead \& Reeves, 1995). A thorough investigation of the Scrophulariaceae utilizing DNA sequences from both the $r b c \mathrm{~L}$ and $n d h \mathrm{~F}$ genes has indicated that the family is comprised of at least two monophyletic groups with several genera not having any strict affinity to the Scrophulariaceae or other related families included in the analysis (Olmstead \& Reeves, 1995). Likewise, Olmstead and Reeves (1995) found that several families traditionally segregated from the Scrophulariaceae are best included as members of one of the two major lineages (e.g., Plantaginaceae).

Although most members of the Lamiales s.l. are temperate, there are some primarily tropical groups (Gesneriaceae, Acanthaceae, Bignoniaceae). In order to better assess whether the division between these families represents another artificial segregation based on distribution (tropical vs. temperate) or woody versus herbaceous (e.g., Bignoniaceae vs. Gesneriaceae), a thorough investigation of the Gesneriaceae was deemed necessary to complement the investigations that have already demonstrated monophyly of Acanthaceae (Scotland et al., 1995) and Bignoniaceae (R. Olmstead, pers. comm.), but have not sampled widely in the Gesneriaceae.

'We are indebted to the following for sharing plant material: L. E. Skog, W. L. Wagner, J. K. Boggan, Strybing Arboretum, M. Kälersjö, B. Nordenstam, R. Dunn, D. Turley, J. Katzenstein, B. Stewart, M. Evans, and the American Gesneriad and Gloxinia Society (AGGS) seed fund. We also thank Richard Olmstead and Michael Kiehn for helpful comments on the manuscript. Funding for this project was provided by NSF grant DEB-9317775 and a grant from AGGS to JFS.

${ }^{2}$ Department of Biology, Boise State University, 1910 University Drive, Boise, Idaho, 83725, U.S.A.

${ }^{3}$ Current address: 1263 Londonderry, Idaho Falls, Idaho, 83404, U.S.A. 
The Gesneriaceae are a mid-sized to large plant family comprising approximately $2500-3500$ species in 120-135 genera, distributed primarily in the tropics with a few temperate species in Europe, China, and Japan (Heywood, 1978; A. Weber, pers. comm.). The majority of species in the Gesneriaceae are herbaceous perennials, but can be annuals, shrubs, lianas, and trees. Many species $(20 \%)$ are epiphytic, and the Gesneriaceae rank among the top ten plant families in terms of absolute numbers of epiphytic taxa (Madison, 1977; Kress, 1986). Given the diverse habits of the Gesneriaceae, it is not surprising that there is a wide array of morphological variation within the family. Corolla tubes may be long and prominent as in $\mathrm{Col}$ umnea L., or short as in Saintpaulia Wendl. Leaves are opposite in the majority of the family, but anisophylly, leading to an alternate arrangement with abscission of the smaller leaf, is common. Many of these morphologically diverse features of the Gesneriaceae are hypothesized as adaptations to the epiphytic habit (Ackerman, 1986).

The Gesneriaceae are a member of the Lamiales s.l. and are distinguished from other families in the order by the combination of five-lobed corollas, parietal placentation, and presence of endosperm in most taxa (Cronquist, 1981). However, because many of these characters vary within some members of the Gesneriaceae (including variation within individuals of some species), there has been considerable confusion regarding the placement of some genera. For example, members with axile placentation can be classified incorrectly with the Scrophulariaceae, and those genera lacking endosperm potentially may be classified with the Acanthaceae and Bignoniaceae.

There have been relatively few cladistic analyses performed within the Gesneriaceae (Kvist, 1990; Crisci et al., 1991; Boggan, 1991; Smith \& Sytsma, 1994a, b, e; Smith, 1996), and only one (Smith, 1996) performed at the tribal level. A cladistic analysis is desirable to help resolve relationships, to determine if the family is monophyletic, and to improve classification within the family by rearranging tribes and subfamilies to reflect phylogenetic relationships.

Classifications of the Gesneriaceae traditionally recognize two subfamilies (Gesnerioideae and Cyrtandroideae) (Bentham, 1876; Burtt, 1962, 1977; Fritsch, 1893, 1894), but others have included an additional subfamily (Coronantheroideae: Wiehler, 1983; Episcioideae: Ivanina, 1965). The division of the family is largely based on the uniform (Gesnerioideae), or uneven (Cyrtandroideae) enlargement of the cotyledons after germination (Burtt,
1962). Another character that has been useful in separating the subfamilies is the presence (Gesnerioideae) or absence (Cyrtandroideae) of endosperm in the seed. In addition, the Gesnerioideae have a neotropical distribution and most species have inferior or semi-inferior ovaries, whereas the Cyrtandroideae are primarily paleotropical with superior ovaries. However, the geographic distribution and ovary position are not consistent within the subfamilies. Therefore, although the Cyrtandroideae can be defined by a synapomorphic character (uneven cotyledon development), the Gesnerioideae have been characterized by a symplesiomorphic character common to dicotyledons in general.

The two subfamilies have been divided further into 9-17 tribes (Bentham, 1876; Burtt, 1962, 1977; Fritsch, 1893, 1894; Ivanina, 1965; Wiehler, 1983; Burtt \& Wiehler, 1995). The classification schemes differ due to the characters emphasized. For example, Fritsch $(1893,1894)$ placed the Columneae in the Cyrtandroideae based on their superior ovary. Later, the Columneae were moved to the Gesnerioideae due to the presence of uniform cotyledons (Burtt, 1962, 1977) and combined into the Episcieae based on nodal anatomy (Wiehler, 1983). This paper presents a cladistic analysis of DNA sequences in order that phylogenetic relationships among taxa may be more clearly resolved, and a more stable classification scheme proposed.

The gene $n d h \mathrm{~F}$ is a chloroplast gene that in tobacco encodes a protein of 740 amino acids presumed to be a subunit of an NADH dehydrogenase (Sugiura, 1992). The use of $n d h \mathrm{~F}$ sequences for systematic studies has provided a far greater number of characters to resolve relationships than studies using $r b c \mathrm{~L}$. The reasons for the increased number of characters are that the gene is approximately $50 \%$ longer than $r b c \mathrm{~L}$ (2103 vs. 1431 bp in tobacco [Wolfe, 1991]) and has a nucleotide substitution rate that is approximately two times higher than $r b c \mathrm{~L}$ based on comparisons of rice and tobacco (Sugiura, 1989). In recent studies using this gene in the Acanthaceae, Scotland et al. (1995) found three times the number of characters compared to $r b c \mathrm{~L}$, and Olmstead and Sweere (1994) discovered $60 \%$ more variable characters with $n d h \mathrm{~F}$ in the Solanaceae. Likewise, Clark et al. (1995) have found that $n d h \mathrm{~F}$ sequences are informative for resolving relationships within the Poaceae, and Olmstead and Reeves (1995) have resolved several clades in a polyphyletic Serophulariaceae. The larger number of variable characters makes $n d h \mathrm{~F}$ sequences ideal for taxonomic groups that have not been resolved well using rbcL data, such as members of the As- 
Table 1. Species sequenced in this study with Genbank submission numbers and voucher specimens. JFS - James F. Smith, WLW - Warren L. Wagner, DEB - Dennis E. Breedlove, SI - Smithsonian Institution, LG - Longwood Gardens. Letters in parentheses indicate herbarium where vouchers are deposited.

\begin{tabular}{|c|c|c|}
\hline Species & Voucher & $\begin{array}{c}\text { Genbank } \\
\text { number }\end{array}$ \\
\hline Achimenes skinneri Lindl. & SI 94-606 & U62177 \\
\hline Aeschynanthus micranthus C. B. Clarke & JFS 643 (WIS) & U62169 \\
\hline Agalmyla parasitica (Lam.) Kuntze & SI $94-570$ & U62171 \\
\hline Alloplectus meridensis Klotzsch & JFS 1182 (WIS) & U62158 \\
\hline Anna mollifolia (W. T. Wang) W. T. Wang \& K. Y. Pan & Skog $94-498$ & U62188 \\
\hline Asteranthera ovata (Cav.) Hanst. & Stewart 12234 (SRP) & U62204 \\
\hline Besleria affinis Morton & LG870575 & U62162 \\
\hline Boea hygroscopica F. Muell. & SI 89-041 & U62205 \\
\hline Chirita sinensis Lindl. & SI $94-111$ & U62189 \\
\hline Codonanthe elegans Wiehler & Sl $82-45$ & U62178 \\
\hline Columnea schiedeana Schlecht. & JFS 288 (WIS) & U62164 \\
\hline Cyrtandra hawaiensis C. B. Clarke & WLW 6753 (BISH) & U62172 \\
\hline Cyrtandra umbellifera Merr. & WLW 6701 (BISH) & U62165 \\
\hline Cyrtandromoea acuminata Benth. \& Hook. & JFS 3539 (SRP) & U62173 \\
\hline Diastema racemiferum Benth. & SI 85-98 & U62156 \\
\hline Didissandra frutescens Clarke & SI 94-512 & U62190 \\
\hline Didymocarpus albomarginata Hemsl. & SI $94-509$ & U62207 \\
\hline Drymonia stenophylla (J. D. Smith) H. E. Moore & JFS 2248 (WIS) & U62159 \\
\hline Fieldia australis Cunn. & Stewart s.n. (SRP) & U62196 \\
\hline Gasteranthus corallinus (Fritsch) Wiehler & SI $94-243$ & U62163 \\
\hline Gesneria pedicellaris Alain & SI $94-567$ & U62192 \\
\hline Gesneria christii Urban & SI $94-507$ & U62191 \\
\hline Gloxinia sylvatica (HBK) Kunth & Dunn 9012051 (SRP) & U62157 \\
\hline Hemiboea henryi C. B. Clarke & SI $85-157$ & U62180 \\
\hline Kohleria spicata (Kunth) Oerst. & SI 94-552 & U62181 \\
\hline Lysionotus pauciflorus Maxim. & SI 94-158 & U62182 \\
\hline Mitraria coccinea Cav. & Stewart s.n. (SRP) & U62193 \\
\hline Monophyllaea hirticalyx Franch. & no voucher & U62168 \\
\hline Monopyle macrocarpa Benth. & no voucher & U62197 \\
\hline Napeanthus costaricensis Wiehler & no voucher & U62198 \\
\hline Napeanthus macrostoma Leeuwenberg & Feuillet (US) & U62161 \\
\hline Negria rhabdothamnoides F. Muell. & Nordenstam $8608(\mathrm{~S})$ & U62195 \\
\hline Nematanthus hirsutus (Mart.) Wiehler & Olmstead \& Reeves, 1995 & L36404 \\
\hline Niphaea oblonga Lindl. & SI $78-354$ & U62160 \\
\hline Opithandra primuloides (Miq.) B. L. Burtt & SI $93-073$ & U62183 \\
\hline Ornithoboea wildeana Craib. & SI 93-075 & U62166 \\
\hline Paliavana prasinata (Ker-Gawl.) Fritsch & SI $78-368$ & U62174 \\
\hline Paraboea rufescens (Franch.) Burtt & Skog s.n. (US) & U62206 \\
\hline Petrocosmea flaccida Craib & SI $85-196$ & U62184 \\
\hline Primulina tabacum Hance & SI 93-040 & U62167 \\
\hline Ramonda myconi (L.) Rehb. & Katzenstein s.n. (SRP) & U62185 \\
\hline Rhynchoglossum notonianum (Wall.) B. L. Burtt & SI $94-378$ & U62179 \\
\hline Rytidophyllum tomentosum (L.) Mart. & SI $77-235$ & U62200 \\
\hline Rytidophyllum auriculatum Hook. & SI 94-524 & U62199 \\
\hline Saintpaulia rupicola B. L. Burtt & SI 94-492 & U62176 \\
\hline Sarmienta repens Ruiz \& Pavón & Stewart s.n. (SRP) & U62194 \\
\hline Sinningia (Lietzia) brasiliensis (Regel \& Schmidt) Wiehler & Dunn 9104014 (SRP) & U62175 \\
\hline Sinningia cooperi (Paxt.) Wiehler & SI 94-340 & U62201 \\
\hline Sinningia richï Clayb. & SI 94-554 & U62186 \\
\hline Solenophora obliqua D. L. Denham \& D. N. Gibson & DEB 71542 (CAS) & U62202 \\
\hline Streptocarpus holstii Engl. & Olmstead \& Reeves, 1995 & L36415 \\
\hline Streptocarpus saxorum Engl. & JFS s.n. (WIS) & U62170 \\
\hline Titanotrichum oldhamï (Hemsl.) Soler. & SI $86-106$ & U62187 \\
\hline
\end{tabular}


Table 1. Continued.

\begin{tabular}{|c|c|c|}
\hline Species & Voucher & $\begin{array}{c}\text { Genbank } \\
\text { number }\end{array}$ \\
\hline Vanhouttea lanata Fritsch & SI $94-516$ & U62203 \\
\hline \multicolumn{3}{|l|}{ Outgroups } \\
\hline Antirrhinum majus $\mathrm{L}$. & Olmstead \& Reeves, 1995 & $\mathrm{~L} 36392$ \\
\hline Brillantaisia lamium Benth. & Scotland et al., 1995 & U12654 \\
\hline Catalpa sp. & Olmstead \& Reeves, 1995 & L36397 \\
\hline Celsia arcturus Jacq. & Olmstead \& Reeves, 1995 & L36398 \\
\hline Crabbea reticulata C. B. Clarke & Scotland et al., 1995 & U12655 \\
\hline Crossandra nilotica Oliv. & Scotland et al., 1995 & U12656 \\
\hline Digitalis grandiflora Mill. & Olmstead \& Reeves, 1995 & L36399 \\
\hline Hygrophila corymbosa Lindau & Scotland et al., 1995 & U12661 \\
\hline Martinella obovata (HBK) Bureau \& K. Schum. & Olmstead \& Reeves, 1995 & L36402 \\
\hline Paulownia tomentosa Steud. & Olmstead \& Reeves, 1995 & L36406 \\
\hline Selago thunbergii Choisy & Olmstead \& Reeves, 1995 & $\mathrm{~L} 36412$ \\
\hline Schlegelia parviflora (Oerst.) Monachino & Olmstead \& Reeves, 1995 & $\mathrm{~L} 36410$ \\
\hline Scrophularia sp. & Olmstead \& Reeves, 1995 & L36411 \\
\hline Tabebuia heterophylla (A. de Candolle) Britton & Olmstead \& Reeves, 1995 & L36416 \\
\hline Verbascum thapsus L. & Olmstead \& Reeves, 1995 & L36417 \\
\hline Veronica catenata Pennell & Olmstead \& Reeves, 1995 & L36419 \\
\hline
\end{tabular}

teridae and Lamiales s.l. (Olmstead et al., 1992, 1993; Chase et al., 1993).

\section{Materials And Methods}

The gene sequences used in this analysis were generated by thermal cycle sequencing (Innis et al., 1988 ) of previously amplified $n d h \mathrm{~F}$ regions. The $n d h \mathrm{~F}$ gene was amplified in two overlapping sections (positions 1-1350, and 972-2044) from genomic DNA isolated from fresh, frozen, or silica gel dried material (Smith et al., 1992). Once amplification products were obtained, the sample was purified using PCR wizard purification preps (Promega) according to the manufacturer's instructions. The purified DNA then was subjected to cycle sequencing using the Silver Sequence method (Promega). This sequencing method resulted in sequences that could be read within six to eight hours after amplification was completed. The products of one round of amplification provided sufficient material for completing the gene sequences described here. The advantages of the silver staining procedure over radioactive methods are safety, minimal waste disposal, and speed.

\section{CHOICE OF TAXA}

The focus of this analysis was on the tribal relationships of the Gesneriaceae and comparison of the results of this analysis with one based on morphological data (Smith, 1996). Genera were selected to represent current and previous tribal classi- fications within the family and, whenever possible, to match genera used in the morphological analysis. In some instances, a genus that had been used with the morphological analysis (Smith, 1996) was not readily available for the molecular analysis. Therefore this molecular analysis contains many taxa that have not been included in the morphological analysis, and direct comparisons will be made with a reduced data set at a future date. The species used in the analysis, voucher information, and Genbank accession numbers are included in Table 1.

Genera have been selected to represent the most recent tribal classifications with two to ten genera from each tribe (Tables 2 and 3). In order to represent current classification systems along with earlier systems, 48 genera were selected (Tables 2 and 3).

\section{OUTGROUP SELECTION}

Outgroups were selected to root the tree representing tribal relationships within Gesneriaceae. The best method for doing this is by outgroup comparison (Donoghue \& Cantino, 1984; Maddison et al., 1984). The most appropriate outgroup for the tribes of the Gesneriaceae should be the most closely related plant family or clade. The Gesneriaceae have been placed in the order Lamiales s.l. in the subclass Asteridae (or equivalent groups of families) in numerous taxonomic treatments (Dahlgren, 1975; Thorne, 1976, 1983, 1992; Heywood, 1978; Takhtajan, 1980; Cronquist, 1981). However, 
Table 2. Genera of Gesnerioideae (Burtt \& Wiehler, 1995) used and their classification status. NT = not treated. Subfamilial names are underlined to readily distinguish them from tribal names. Subtribal names are abbreviated as Colum. - Columneineae, Codon. - Codonanthinae.

\begin{tabular}{|c|c|c|c|}
\hline Genus & Wiehler, 1983 & Ivanina, 1965 & Fritsch, 1893-94 \\
\hline & Gesnerioideae & Gesnerioideae & Gesnerioideae \\
\hline Achimenes & $\overline{\text { Gloxinieae }}$ & $\overline{\text { Gloxinieae }}$ & $\overline{\text { Gloxinieae }}$ \\
\hline Gloxinia & Gloxinieae & Gloxinieae & Gloxinieae \\
\hline Monopyle & Gloxinieae & Bellonieae & Bellonieae \\
\hline Niphaea & Gloxinieae & Bellonieae & Bellonieae \\
\hline Kohleria & Gloxinieae & Kohlerieae & Kohlerieae \\
\hline Diastema & Gloxinieae & Kohlerieae & Kohlerieae \\
\hline Sinningia & Gloxinieae & Kohlerieae & Sinningieae \\
\hline Vanhouttea & Gloxinieae & Kohlerieae & Kohlerieae \\
\hline Paliavana & Gloxinieae & Reichsteinerieae & Kohlerieae \\
\hline Lietzia & Gloxinieae & Reichsteinerieae & Sinningieae \\
\hline Solenophora & Gloxinieae & Solenophoreae & Solenophoreae \\
\hline Gesneria & Gloxinieae & Gesnerieae & Gesnerieae \\
\hline \multirow[t]{2}{*}{ Rytidophyllum } & $=$ Gesneria & Gesnerieae & Gesnerieae \\
\hline & & Episcioideae & Cyrtandroideae \\
\hline Columnea & Episcieae & $\overline{\text { Columneae }}$ & $\overline{\text { Columneae-Colum. }}$ \\
\hline Codonanthe & Episcieae & Columneae & Columneae-Codon. \\
\hline Nematanthus & Episcieae & Columneae & Columneae-Colum. \\
\hline Alloplectus & Episcieae & Episcieae & Columneae-Colum. \\
\hline Drymonia & Episcieae & Episcieae & Columneae-Colum. \\
\hline Besleria & Beslerieae & Episcieae & Beslerieae \\
\hline Gasteranthus & Beslerieae & NT & NT \\
\hline \multirow[t]{2}{*}{ Napeanthus } & Napeantheae & Episcieae & Klugieae \\
\hline & Coronantheroideae & Cyrtandroideae & \\
\hline Asteranthera & Coronanthereae & $\overline{\text { Mitrarieae }}$ & Coronanthereae \\
\hline Sarmienta & Coronanthereae & Mitrarieae & Coronanthereae \\
\hline Mitraria & Coronanthereae & Mitrarieae & Coronanthereae \\
\hline Fieldia & Coronanthereae & Mitrarieae & Coronanthereae \\
\hline Negria & Coronanthereae & Coronanthereae & Coronanthereae \\
\hline
\end{tabular}

the relationships among these families are somewhat ambiguous. A recent cladistic analysis of these families based on DNA sequencing of the chloroplast encoded $r b c \mathrm{~L}$ gene resulted in poor resolution of the relationships of these families $(\mathrm{Olm}-$ stead et al., 1993), although these relationships have been more resolved with the addition of $n d h \mathrm{~F}$ sequences (Olmstead \& Reeves, 1995).

Three families from the Lamiales s.l. were used as outgroups for this analysis. These were the Acanthaceae, Bignoniaceae, and Serophulariaceae. Sequences for sixteen species of these three families were obtained via Genbank (Table 1; Olmstead \& Reeves, 1995; Scotland et al., 1995) and included representatives from three lineages identified within the Scrophulariaceae (Olmstead \& Reeves, 1995). Initial analyses used all 16 species as the outgroup. Subsequent analyses used only Gesneriaceae with Paulownia Sieb. \& Zucc. as the outgroup.

\section{PHYLOGENETIC ANALYSIS}

Phylogenetic divergence was reconstructed using PAUP version 3.1.1 (Swofford, 1993) to implement Wagner parsimony (Farris, 1970; Farris et al., 1970; Swofford \& Maddison, 1987). This program allows parallelisms and reversals (homoplasy), and provides an option for missing data. In this analysis, trees were generated using the general heuristic option, saving minimal trees only, with the collapse zero-length branches, and ignore uninformative characters options in effect. Because of the large number of taxa in this analysis, the branch and bound and exhaustive search options would have consumed an excessive amount of time. Therefore, the trees presented here are best approximations and not exact solutions. The manner in which the program reconstructs phylogenetic sequences is sensitive to the order of taxa presentation in the data matrix, frequently finding islands of equally parsimonious trees depending on the order (Mad- 
Table 3. Genera of Cyrtandroideae (Burtt \& Wiehler, 1995) used and their classification status. NT $=$ not treated. The tribe, Didymoearpeae, is abbreviated Didy. in order to show the subtribal classification system of Ivanina (1965) and Fritsch (1893, 1894).

\begin{tabular}{|c|c|c|c|}
\hline Genus & Burtt, 1962,77 & Ivanina, 1965 & Fritsch, 1893-94 \\
\hline Ramonda & Didymocarpeae & Ramondeae & Ramondeae \\
\hline Saintpaulia & Didymocarpeae & Saintpaulieae & Ramondeae \\
\hline Opithandra & Didymocarpeae & Didy.-Roettlerineae & NT \\
\hline Didymocarpus & Didymocarpeae & Didy.-Roettlerineae & Didy--Roettlerineae \\
\hline Didissandra & Didymocarpeae & Didy.-Roettlerineae & Didy-Oreacharineae \\
\hline Anna & Didymocarpeae & Didy.-Roettlerineae & NT \\
\hline Chirita & Didymocarpeae & Didy,-Roettlerineae & Didy,-Roettlerineae \\
\hline Petrocosmea & Didymocarpeae & Didy.-Roettlerineae & Ramondeae \\
\hline Titanotrichum & anomalous & NT & NT \\
\hline Cyrtandromoea & Loxonieae/Scroph. & Klugieae & Beslerieae \\
\hline Paraboea & Didymocarpeae & Didy.-Roettlerineae & Didy.-Roettlerineae \\
\hline Boea & Didymocarpeae & NT & Streptocarpeae \\
\hline Hemiboea & Didymocarpeae & Didy.-Roettlerineae & NT \\
\hline Primulina & Didymocarpeae & Didy.-Roettlerineae & Klugieae \\
\hline Streptocarpus & Didymocarpeae & Didy.-Streptocarp. & Streptocarpeae \\
\hline Ornithoboea & Didymocarpeae & Didy.-Streptocarp. & Streptocarpeae \\
\hline Aeschynanthus & Trichosporeae & Trichosporeae & Trichosporeae \\
\hline Agalmyla & Trichosporeae & Trichosporeae & Trichosporeae \\
\hline Lysionotus & Trichosporeae & Trichosporeae & Trichosporeae \\
\hline Cyrtandra & Cyrtandreae & Cyrtandreae & Cyrtandreae \\
\hline Rhynchoglossum & Klugieae & Klugieae & Klugieae \\
\hline Monophyllaea & Klugieae & Klugieae & Beslerieae \\
\hline
\end{tabular}

dison, 1991). Therefore, it is important to repeat the analysis several times. To do this, the search strategy of Olmstead and Palmer (1994) was implemented: searching for 1000 trees each in five subsequent analyses with the nearest neighbor interchange (NNI) search option in effect and mulpars "off." Each of the results from the five NNI searches was used as the starting tree(s) for a search with tree bisection reconnection (TBR) and mulpars "on." This strategy was used in the full analysis with all 16 non-Gesneriaceae taxa designated as outgroups. Likewise, the same strategy was used with only the members of the Gesneriaceae and Paulownia as the outgroup, and with constraints options.

Branch support analysis was performed to examine trees that were six or fewer steps longer than the most-parsimonious tree (Bremer, 1988; Donoghue et al., 1992; Bremer, 1994). This type of analysis provides an indication of the robustness of the data by determining which clades persist in a consensus tree as parsimony is relaxed. This analysis was performed by saving all trees six steps longer than the most-parsimonious trees and then examining subsets of trees one to six steps longer with the filter option of PAUP.

The $n d h \mathrm{~F}$ sequences used here had several six to twelve base pair insertions or deletions (indels) inferred from gaps in the sequence alignments, which in previous analyses had been re-scored as binary characters and used as either an independent data set or combined with the sequence data (Scotland et al., 1995). These indels were viewed as having phylogenetic importance (Scotland et al., 1995); therefore indels found in the Gesneriaceae were removed and examined independently of sequence data for their phylogenetic utility.

The monophyly of various tribal relationships not obtained in the most-parsimonious trees was examined by using the constraints option of PAUP. These included the Trichosporeae, the Didymocarpeae, the inclusion of Klugieae in Cyrtandroideae, and Sinningieae in Gloxinieae. Also, since the analysis with all 16 outgroup taxa resulted in the placement of Nematanthus Schrader and Klugieae in discrepant positions from traditional classifications, an analysis with all 16 outgroups constrained Nematanthus to the Gesnerioideae, and the Klugieae from the Gesnerioideae. The position of Klugieae and Nematanthus was also examined by constructing a user-defined tree with a topology of one of the two most-parsimonious trees except that $\mathrm{Ne}$ matanthus was placed in the Episcieae, and Klugieae was placed as sister to the remainder of the Gesneriaceae. This user-defined tree was then the 
starting tree for a search using TBR and mulpars "on."

\section{RESULTS}

Complete sequences for the $n d h \mathrm{~F}$ gene were obtained for 52 species of Gesneriaceae (Table 1). These sequences were supplemented with sequences from an additional 18 species ( 2 within Gesneriaceae and 16 from related families) from Genbank (Table 1). The complete sequences resulted in 849 phylogenetically informative characters among all 70 species in the full analysis. A smaller analysis focused on only the Gesneriaceae species with Paulownia as the outgroup. Within this smaller analysis 690 nucleotide positions were found to be phylogenetically informative. Indels were found at several positions in the Gesneriaceae from the sequences used in this analysis. Two widespread insertions were a $12 \mathrm{bp}$ insertion at position 1440 and a 6 bp insertion at 1548 . Other insertions were autapomorphic for species or genera used in the analysis (unpublished results). No insertions were used in the analysis. The 6 bp insertion was symplesiomorphic for the Gesneriaceae. The 12 bp insertion was also symplesiomorphic for the Gesneriaceae; however, sequence divergence within this insertion provides an additional synapomorphy for the clade comprised of Columnea, Drymonia Mart., and Alloplectus Mart. (Fig. 4), where a single base pair transition characterizes these three genera. Other base pair substitutions and insertions were found within this $12 \mathrm{bp}$ insertion but, with the current level of sampling, were autapomorphic.

Cladistic analysis was performed initially with all 70 taxa of the four families (Gesneriaceae, Scrophulariaceae, Acanthaceae, and Bignoniaceae) and all taxa in the three outgroup families designated as the outgroup. This analysis resulted in two trees of 5610 steps each (consistency index $(\mathrm{CI})=0.30$, retention index $(R I)=0.48)$, all of which indicated the Gesneriaceae were a monophyletic family and that the genus Paulownia (Scrophulariaceae) was the closest outgroup (Figs. 1, 2).

Subsequent analyses were performed to minimize computer analysis time that utilized only the Gesneriaceae and Paulownia as a designated outgroup. This reduced analysis resulted in a single mostparsimonious tree of 4613 steps $(\mathrm{CI}=0.27, \mathrm{RI}=$ 0.38 ) (Figs. 3, 4). Some taxa that have been thought to be monophyletic, or comprised tribes, were examined using the constraints option of PAUP to determine the impact of the monophyletic grouping on the remainder of the data and to determine the number of additional steps required to construct these trees. The analysis required four additional steps to create a monophyletic Trichosporeae, five for a monophyletic Didymocarpeae, two to include the Klugieae in the Cyrtandroideae, and four to include the Sinningieae in the Gloxinieae. Constraining the analysis of all 70 taxa to place Klugieae as the sister to the Gesneriaceae and $\mathrm{Ne}$ matanthus within the Episcieae resulted in four trees 58 steps longer than the most-parsimonious trees regardless of whether the constraint option of PAUP, or user defined trees were implemented.

\section{Discussion}

The cladistic analysis of 54 species of Gesneriaceae with 16 species of Scrophulariaceae, Bignoniaceae, and Acanthaceae as outgroups resulted in a monophyletic Gesneriaceae with the single genus Paulownia (Scrophulariaceae) indicated as the closest outgroup (Figs. 1, 2). These results verified that the Gesneriaceae are distinct from other members of the Lamiales s.l, and not an artificial unit based on their largely tropical distribution and herbaceous habit as has been seen for some family pairs (Judd et al., 1994). The full analysis is largely in agreement with the position of the taxa in the reduced analysis with the exception of the positions of Nematanthus and the tribe Klugieae. The placement of Nematanthus as the sister to the remainder of the family is very far removed from its traditional classification within the Episcieae (Fig. 1). Likewise the Klugieae are placed unusually in the subfamily Gesnerioideae (Fig. 2). The most likely explanation for the anomalous placement of these taxa is the high level of homoplasy between the Gesneriaceae and the outgroups. This is exemplified when 15 of the 16 outgroup species are removed from the analysis. In the reduced analysis both $\mathrm{Ne}$ matanthus and Klugieae are in more expected positions regarding relationships to the remainder of the family. An alternative explanation is that because of the size of the data set, PAUP did not find the shortest tree and that a shorter tree with all 70 species exists that places Nematanthus and the Klugieae in their more expected relationships. This latter explanation is unlikely since searches constraining these taxa to their more traditional positions, or a user-defined tree that placed them there, resulted in four trees that were 58 steps longer.

The reduced analysis resulted in a single mostparsimonious tree (Figs. 3, 4). Three major monophyletic divisions within the family correspond to subfamilies Gesnerioideae and Cyrtandroideae (minus tribe Klugieae) and tribe Klugieae in a separate position as a potential third subfamily. Traditional 


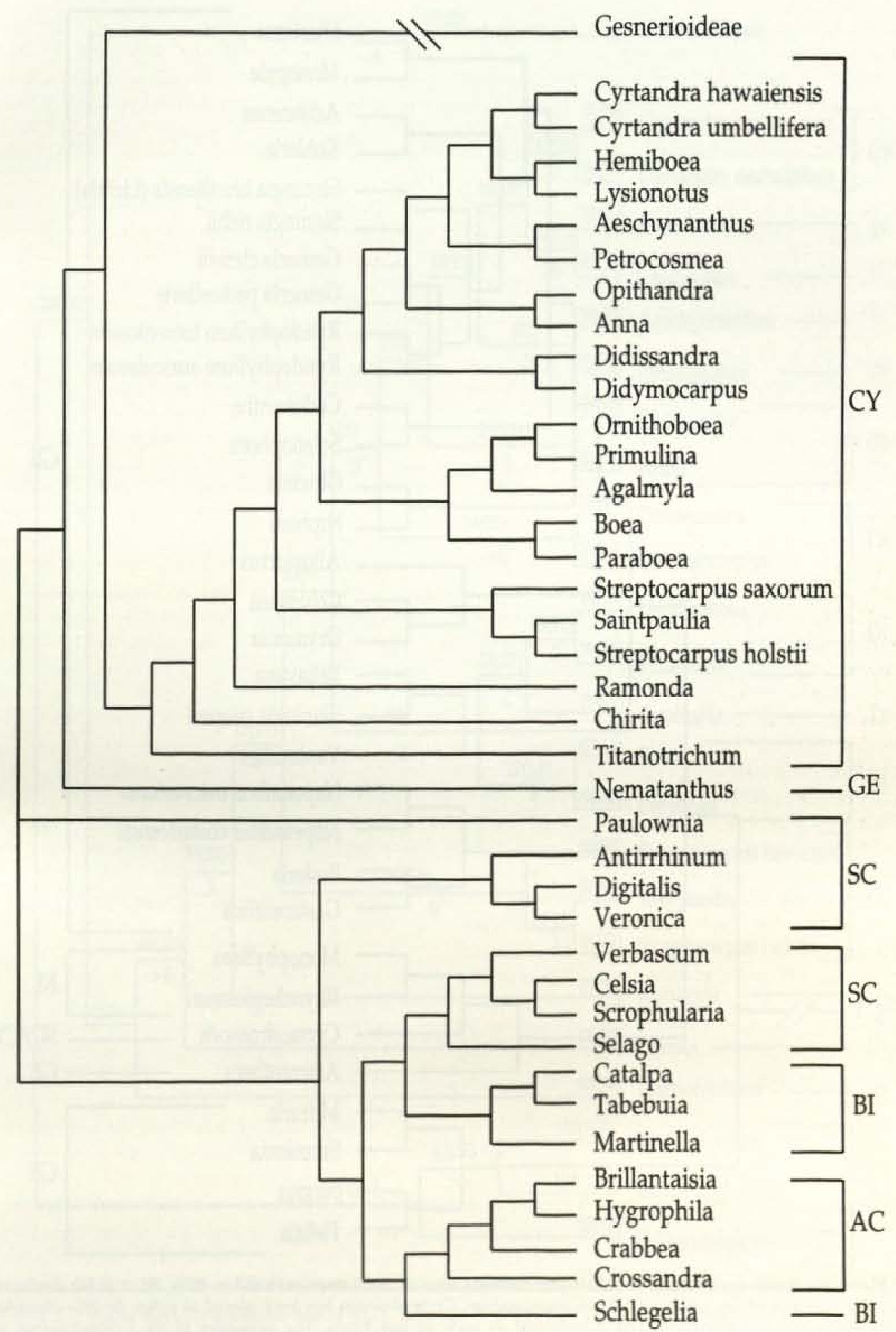

Figure 1. Strict consensus of two most-parsimonious trees of 5610 steps each $(\mathrm{CI}=0.30, \mathrm{RI}=0.48)$ displaying the outgroup taxa, BI-Bignoniaceae, AC-Acanthaceae, SC-Scrophulariaceae, and the subfamilies of the Gesneriaceae, GE-Gesnerioideae and CY-Cyrtandroideae. The remainder of the Gesnerioideae are displayed in Figure 2. See text for explanation of position of Nematanthus in this cladogram. 


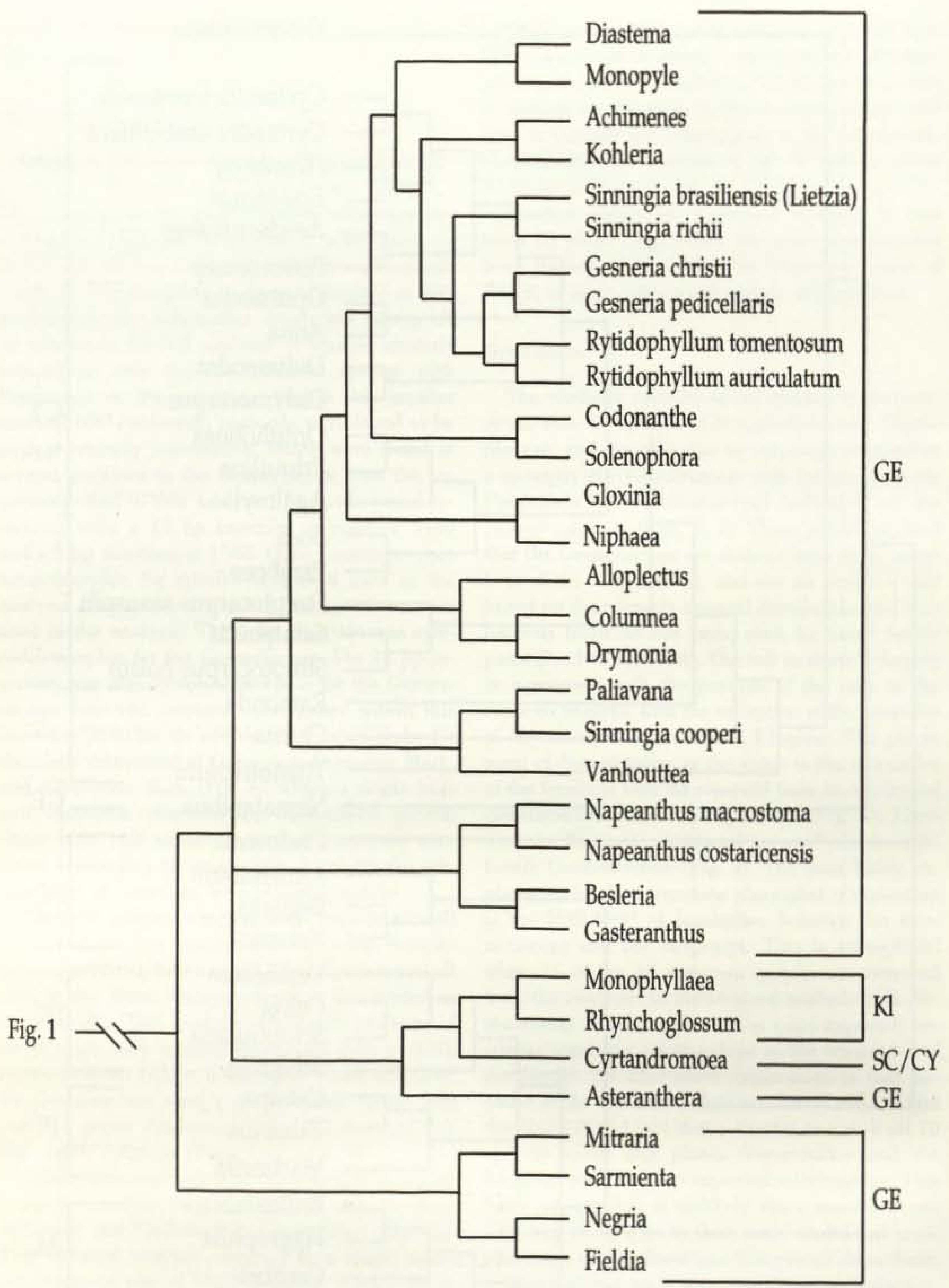

Figure 2. Strict consensus of two most-parsimonious trees of 5610 steps each $(\mathrm{CI}=0.30, \mathrm{RI}=0.48)$ displaying the GE-Gesnerioideae, and some CY-Cyrtandroideae. Cyrtandromoea has been placed in either the SC-Scrophulariaceae or the Cyrtandroideae and is indicated as such on this figure. The remainder of the Cyrtandroideae are displayed in Figure 1. See text for the explanation of position of the tribe Klugieae (KI) in this cladogram. 


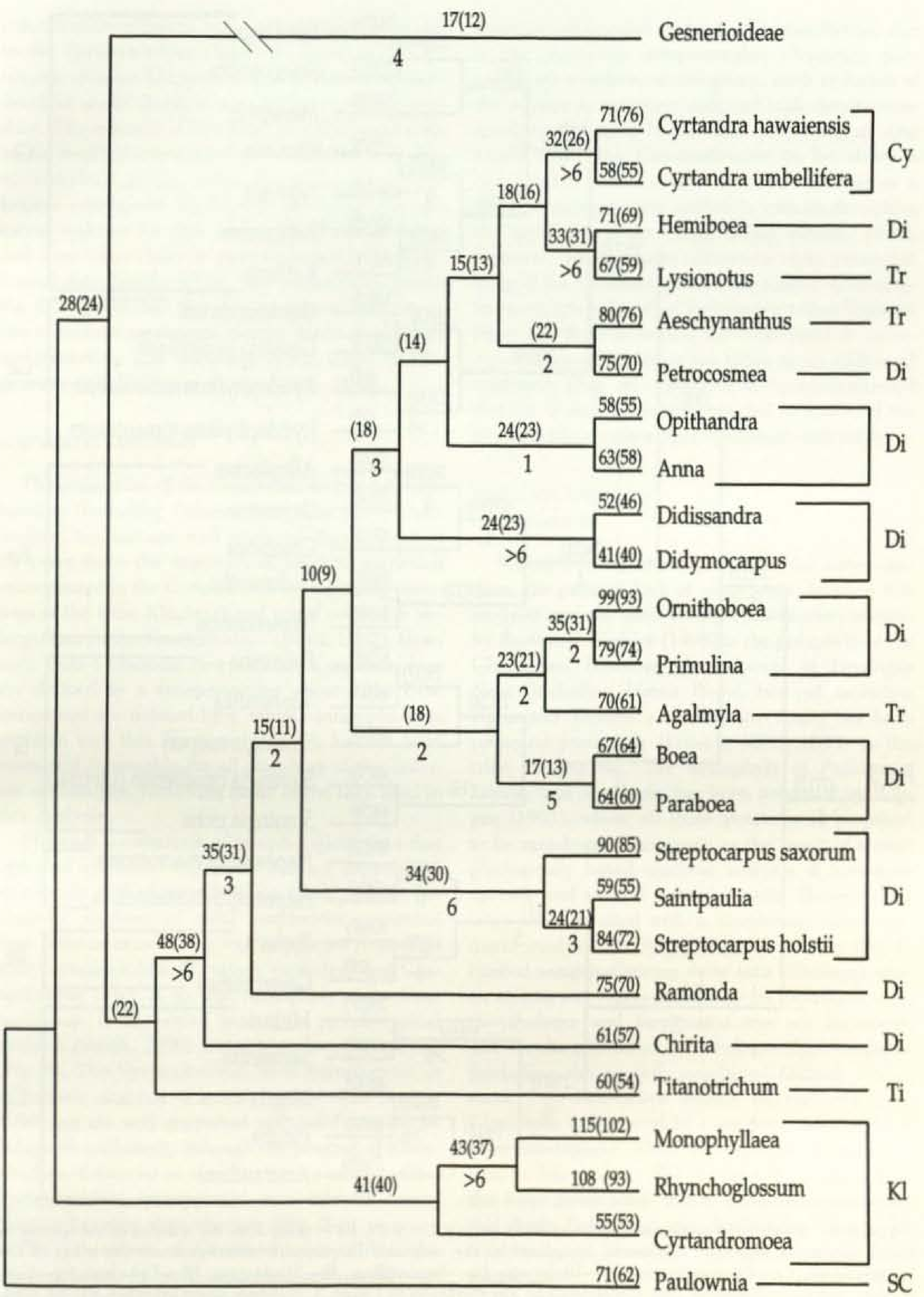

Figure 3. Single most-parsimonious tree of 4613 steps $(\mathrm{CI}=0.29, \mathrm{RI}=0.38)$ from the analysis of the species in the Gesneriaceae with only Paulownia (SC-Serophulariaceae) designated as the outgroup. Displayed in this figure are the tribes of the Cyrtandroideae, KJ-Klugieae, $\mathrm{T}$ - Titanotricheae, Di-Didymocarpeae, $\mathrm{Tr}$ - Trichosporeae, and $\mathrm{Cy}$ Cyrtandreae. The Gesnerioideae are displayed in Figure 4. Numbers along branches are the synapomorphies that support those clades. Numbers in parentheses indicate those synapomorphies that are homoplastic in this tree. Numbers below branches are decay values. Branches with no value indicated have a decay value of 1 . 


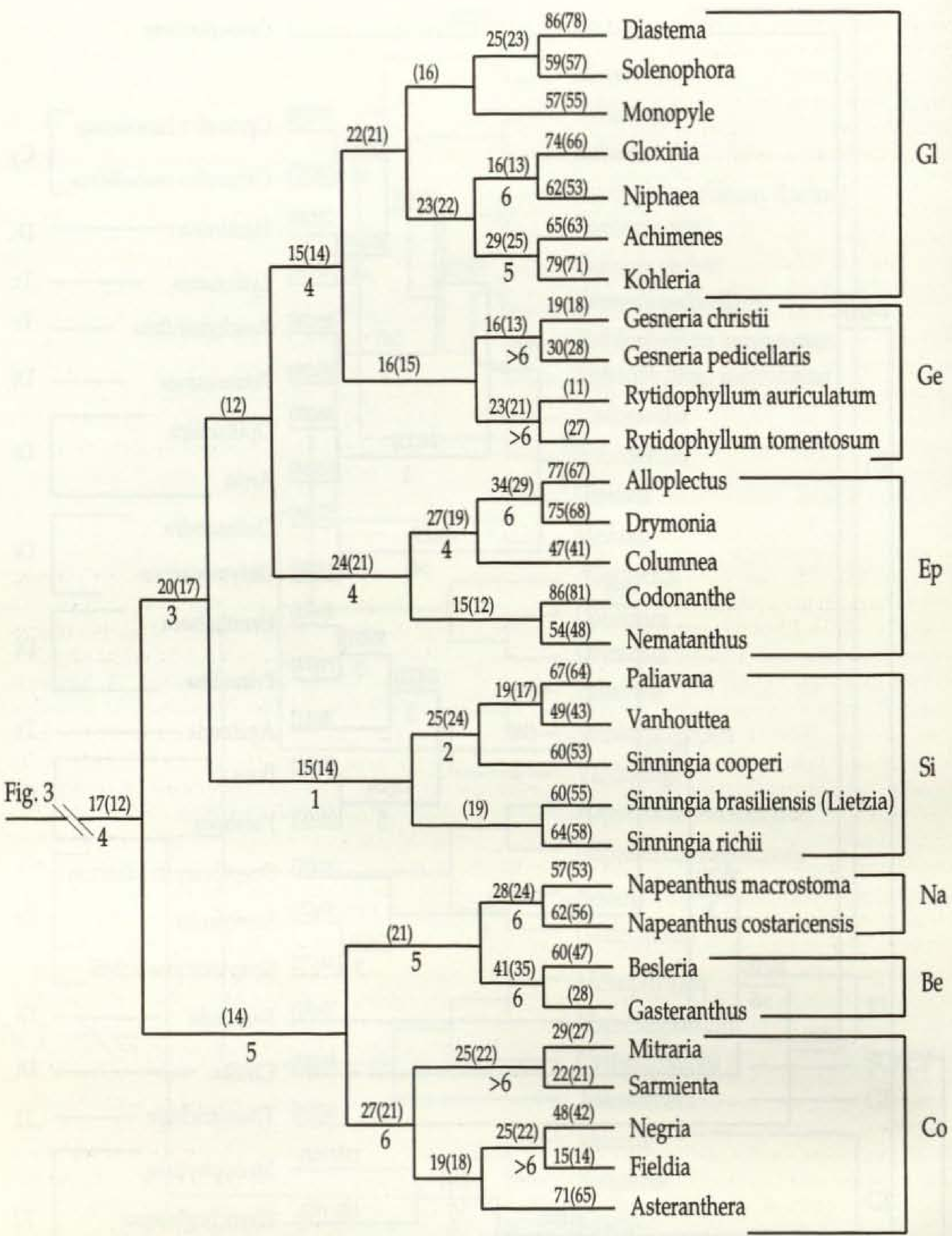

Figure 4. Single most-parsimonious tree of 4613 steps $(\mathrm{Cl}=0.29 . \mathrm{RI}=0.38)$ from the analysis of the species in the Gesneriaceae with only Paulotonia designated as the outgroup. Displayed in this figure are the tribes of the Gesnerioideae, $\mathrm{Co}_{0}$-Coronanthereae, Be-Beslerieae, $\mathrm{Na}$-Napeantheae, Si-Sinningieae, Ep-Episcieae, Ge-Gesnerieae, and $\mathrm{Gl}-$ Gloxinieae. The Cyrtandroideae are displayed in Figure 3. Numbers along branches are the synapomorphies that support those clades. Numbers in parentheses indicate those synapomorphies that are homoplastic in this tree. Numbers below branches are decay values. Branches with no value indicated have a decay value of 1 . 
classification schemes have placed tribe Klugieae in the Cyrtandroideae (Table 3); however, the inclusion of tribe Klugieae within subfamily Cyrtandroideae would result in a paraphyletic Cyrtandroideae. The removal of this tribe to a third subfamily would result in a monophyletic Cyrtandroideae. The monophyletic groups within the subfamily Gesnerioideae correspond highly with traditional classification systems for this subfamily (Wiehler, 1983) and a previous cladistic analysis based on morphological data (Smith, 1996). The relationships within the Cyrtandroideae are less congruent with previous taxonomic treatments, mainly due to the limited understanding and sampling of the large, heterogeneous tribe Didymocarpeae (Burtt, 1962).

\section{SUBFAMILIAL GROUPINGS}

The separation of the Gesneriaceae into two subfamilies (including Coronanthereae in the Gesnerioideae) has become well accepted during the past 30 years since the discovery of unequal cotyledon enlargement in the Cyrtandroideae (including members of the tribe Klugieae) and equal cotyledon enlargement in the Gesnerioideae (Burtt, 1962). However, from a cladistic viewpoint the Cyrtandroideae are defined by a synapomorphy whereas the Gesnerioideae are defined by a symplesiomorphy. One problem with this character is that it has not been examined thoroughly for all members of the different subfamilies, including many of the taxa used in this analysis.

Although an analysis of morphological data that included cotyledon expansion did not support the monophyly of the Cyrtandroideae (Smith, 1996), the cladistic analysis of $n d h \mathrm{~F}$ sequences presented here demonstrates both a well-supported monophyletic Cyrtandroideae (Klugieae excluded) and Gesnerioideae (Figs. 3, 4). The monophyly of the Gesnerioideae is supported in both a morphological analysis (Smith, 1996) and this molecular analysis (Fig. 4). The Cyrtandroideae were paraphyletic in a cladistic analysis of morphological data (Smith, 1996) but are well supported with $n d h \mathrm{~F}$ sequences (Klugieae excluded), although the position of Titanotrichum Solereder as sister to the remainder of the Cyrtandroideae is supported with only 22 homoplastic character state changes (Fig. 3).

The placement of Coronanthereae within the Gesnerioideae is well supported with $n d h \mathrm{~F}$ sequences (Fig. 4) as it is with morphological data (Smith, 1996). This tribe does not belong in the subfamily Cyrtandroideae as had been proposed earlier (Fritsch, 1894). Wiehler (1983) in his treatment of the neotropical Gesneriaceae suggested a separate subfamilial status for Coronanthereae due to the numerous autapomorphic characters possessed by members of this group, such as fusion of the nectary to the ovary wall and high chromosome numbers (Wiehler, 1983). The morphological data would allow the Coronanthereae to be either a monophyletic tribe within the Gesnerioideae or a separate monophyletic subfamily without disrupting the taxonomy of any other group (Smith, 1996). However, based on the molecular data presented here, if the Coronanthereae were raised to subfamily level, it would either include the tribes Napeantheae and Beslerieae from the Gesnerioideae or necessitate elevating these two tribes as an additional subfamily (Fig. 4). Therefore it is recommended that the Coronanthereae be treated as a tribe of the Gesnerioideae rather than a separate subfamily.

\section{TRIBAL REL.ATIONSHIPS}

\section{GESNERIOIDEAE}

Among the relationships within the Gesnerioideae, the primary lack of congruence between this analysis and the most recent classification scheme by Burtt and Wiehler (1995) is the polyphyly of the Gloxinieae. However, the removal of Sinningia Nees (including Lietzia Regel, but not including Paliavana Vandelli or Vanhouttea Lem.) has been proposed previously (Fritsch, 1893, 1894) as the tribe Sinningieae. The monophyly of Paliavana, Lietzia, and Sinningia has been proposed by Boggan (1991), where all three genera were proposed to be members of Sinningia as the result of a morphologically based cladistic analysis of Sinningia species and several related genera. These results were not supported with a morphology-based cladistic analysis (Smith, 1996), most likely due to limited sampling among these taxa (Sinningia sensu stricto was represented only by Sinningia sect. Corytholoma and Vanhouttea was not included). The results presented here indicate that Sinningia (including the recently combined Lietzia), Paliavana, and Vanhouttea should be removed from Gloxinieae and placed in a separate monophyletic tribe Sinningieae. Although Sinningia is paraphyletic in this analysis (Fig. 4), limited sampling from this large genus leads only to a tentative conclusion that both Paliavana and Vanhouttea should be combined into Sinningia to create a monophyletic genus.

The sister relationship of the Beslerieae and $\mathrm{Na}$ peantheae has been hinted at based on the overlap of several diagnostic characters between these tribes (Skog, 1995; Skog \& de Jesus, 1996). However, the sister relationship of these two tribes to 
the Coronanthereae (Fig. 4) has not been proposed previously. Although the morphological data did not indicate sister group status, the data did indicate a close affinity among these three tribes (Smith, 1996).

Among the recent classification schemes proposed for the Gesnerioideae, Burtt and Wiehler's (1995) is the closest approximation to the results obtained in this study. The subdivision of Wiehler's (1983) Gloxinieae into the Bellonieae, Kohlerieae, Rechsteinerieae, and Solenophoreae (Ivanina, 1965) (Table 2) is not supported by this cladistic analysis. Likewise separating Wiehler's (1983) Gloxinieae into Bellonieae, Kohlerieae, and Solenophoreae (Table 2; Fritsch, 1893, 1894) is not supported except for the removal of the Sinningieae (Fig. 4), which would also necessarily include $\mathrm{Pal}$ iavana and Vanhouttea (included in Fritsch's Kohlerieae; Table 2). The placement of Napeanthus G. Gardner in the Klugieae (Cyrtandroideae) (Table 2) as proposed by Fritsch $(1893,1894)$ is inappropriate.

\section{CYRTANDROIDEAE}

Burtt's (1962, 1977) classification system for the Cyrtandroideae is closer in agreement to this cladistic analysis than previous classification schemes (Ivanina, 1965; Fritsch, 1893, 1894). However, the monophyly of the largest tribe, the Didymocarpeae, is not supported by this analysis (Fig. 3). Likewise none of the subtribes created by Ivanina (1965) or Fritsch $(1893,1894)$ are supported as monophyletic groups (Fig. 3, Table 3). The Trichosporeae are not supported as a monophyletic clade (Fig. 3). Although this tribe was well supported in the morphological analysis (Smith, 1996), four additional steps beyond the most-parsimonious tree are required to make this clade monophyletic with $n d h \mathrm{~F}$ data.

The position of Titanotrichum has been problematic, although this genus has consistently remained in the Gesneriaceae (Burtt, 1962, 1977; Wang et al., 1992; Burtt \& Wiehler, 1995). Titanotrichum is a member of the Cyrtandroideae based on these data, and perhaps may be viewed best as a monotypic tribe (Titanotricheae; Wang et al., 1992), sister to the remainder of the subfamily. However, the position of Titanotrichum as the sister to the remainder of the Cyrtandroideae is only weakly supported with 22 homoplastic character state changes, and the resolution of its placement is lost in the strict consensus of all trees only one step longer than the most-parsimonious tree. Therefore, it is likely that Titanotrichum, or the lineage leading to this species, diverged early in the evolution of the family. The placement of Titanotrichum within the Gesneriaceae is discussed elsewhere (Smith et al., 1997).

The Didymocarpeae are a large heterogeneous tribe that includes the majority of genera in the Cyrtandroideae (Burtt, 1962, 1977; Wang et al., 1992). In this analysis it is a paraphyletic assemblage that includes the Cyrtandreae and Trichosporeae (Figs. 1,3). Because of the large size of the Didymocarpeae, and the limited sampling of the tribe in this analysis, no conclusions regarding its monophyly, or potential division into other tribes, are recommended at this time. Further morphological investigations in this tribe are under way (B. L. Burtt and A. Weber, pers. comm.), and a cladistic analysis that focuses on this group will be valuable toward understanding its relationships. Several well-supported monophyletic groups within the Didymocarpeae can be identified (Boea Commerson ex Lamarck/Paraboea (C. B. Clarke) Ridley, Hemiboea C. B. Clarke/Lysionotus D. Don, Didissandra C. B. Clarke/Didymocarpus Wallich, and Streptocarpus Lindl./Saintpaulia). It should be noted that Didissandra and Didymocarpus, although forming a monophyletic clade in this analysis, are both large heterogeneous genera and that sampling different species may have resulted in different placement. By focusing on morphological characters of these groups it may be possible to identify more inclusive monophyletic tribes out of the paraphyletic Didymocarpeae. Much greater sampling within this large group will be necessary before any major realignment can begin.

An unexpected result of this analysis is the paraphyly of Streptocarpus. The most likely explanation for this paraphyly is limited sampling, with only two species of Streptocarpus and one of Saintpaulia. However, it is interesting to note that Saintpaulia is one of the few genera within the Gesneriaceae to have a chromosome number of $n=15$ (Skog, 1984). The only other genera that share this number are some species of Streptocarpus, including both $S$. saxorum and $S$. holstii, and some species of Aeschynanthus Jack (Skog, 1984). The possibility that Saintpaulia is derived from within Streptocarpus, as indicated by $n d h \mathrm{~F}$ sequences and chromosome numbers, currently is being investigated with greater sampling.

The Trichosporeae traditionally have been viewed as a monophyletic tribe defined by the presence of seed appendages not present elsewhere within the family (Burtt, 1962, 1977; Wang et al., 1992). Based on morphological data, the Trichosporeae were one of the most strongly supported 
tribes in a morphology-based cladistic analysis (Smith, 1996). However, it is apparent from this analysis of $n d h \mathrm{~F}$ sequences that the selection of characters that define the Trichosporeae is inappropriate (e.g., seed appendages are common in the closely related Bignoniaceae). Alternatively, it is possible that inadequate sampling from the Trichosporeae or the large tribe Didymocarpeae may be causing the separate placement of the three genera sampled from the Trichosporeae. This latter hypothesis is unlikely, because one of the more strongly supported clades in the analysis placed $L y$ sionotus (Trichosporeae) with Hemiboea (Didymocarpeae) and away from the other genera of the Trichosporeae (Fig. 3).

\section{KLUGIEAE}

The Klugieae are monophyletic and are the sister group to the remainder of the Gesneriaceae (Fig. 3). The placement of this tribe in the Gesnerioideae (Fig. 2) in the full data analysis most likely is due to homoplasy or the result of an incomplete search for the shortest tree. The monophyly and sister group status of this tribe also was supported with a cladistic analysis of morphological data (Smith, 1996). The Klugieae possess numerous autapomorphic characters relative to other Gesneriaceae such as narrow medullary rays, and verrucate edges of the cells of the seed coat (Smith, 1996). The placement of Cyrtandromoea Zoll. in the Klugieae of the Cyrtandroideae was proposed previously by Ivanina (1965), although other investigations indicated that this genus should be excluded from the Gesneriaceae on the basis of floral anatomy (Burtt, 1965; Singh \& Jain, 1978). The placement of $\mathrm{Cyr}_{\mathrm{r}}$ tandromoea in the Gesneriaceae is discussed elsewhere (Smith et al., 1997).

\section{EVOLUTION OF NON-MOLECULAR CHARACTER STATES CHROMOSOME NUMBERS}

Several chromosome counts are synapomorphic and non-homoplastic based on this cladistic analysis. Large numbers of chromosomes $(n=30+)$ are unique to the Coronanthereae and would serve as an additional character to separate this tribe from the remainder of the family (Skog, 1984). A chromosome base number, $x$, of 14 characterizes the Gesnerieae (Wiehler, 1983; Skog, 1984). The cladistic analysis of morphological data was unable to separate the Gesnerieae from the tribe Gloxinieae although it represented a monophyletic group within it (Smith, 1996). The inclusion of chromosome numbers (which were excluded due the large number of character states) might have removed Ges- nerieae from Gloxinieae as seen here with sequence data.

Most Gloxinieae sampled here (excluding Solenophora Benth., Niphaea Lindl., and Achimenes Pers.) have $x=13$ (Wiehler, 1983; Skog, 1984). In addition, the members of the Sinningieae that have been examined also have $x=13$ (Skog, 1984). This similarity in chromosome base number, along with other character states, has led previous researchers to include the members of the Sinningieae within the Gloxinieae (Wiehler, 1983). However, based on the analysis presented here, the Sinningieae are best viewed as a tribe separated from the Gloxinieae, and $x=13$ is homoplastic.

Other homoplastic chromosome numbers are $x=$ 11 (Niphaea and Achimenes), and $x=9$ (Alloplectus, Drymonia, Columnea, and some Didymocarpus species). Although most of these homoplastic counts serve little phylogenetic utility, the count of $x=9$ serves to characterize a portion of the Episcieae. Most members of the Episcieae have $x=$ 9 , but taxa with $x=8$ (Codonanthe (Mart.) Hanst. and Nematanthus) may represent another clade (Fig. 4). Further sampling within the Episcieae may reveal if this clade (Fig. 4) continues to be supported or is the result of sampling in this analysis.

Other chromosome counts in the Cyrtandroideae are highly variable even within genera, and no pattern emerges from the counts of the species that have been included in the analysis, with the exception of the Streptocarpus/Saintpaulia counts discussed above.

\section{NODAL. ANATOMY}

Another useful character for the Gesneriaceae is nodal anatomy (Wiehler, 1983). Unfortunately only the subfamily Gesnerioideae has been sampled thoroughly for this character, and the lack of data for the Cyrtandroideae necessitated the exclusion of this character from the morphological analysis (Smith, 1996). However, if nodal anatomy is mapped onto the trees from this molecular analysis, this character can provide useful phylogenetic information. The tribe Episcieae (Fig. 4) is defined by a three-trace trilacunar node that is unique among the Gesnerioideae, although this character state is known from the Cyrtandroideae. The unique presence of this character state within the Gesnerioideae adds further support to the monophyly of the Episcieae. The three-trace trilacunar node may be symplesiomorphic for the Cyrtandroideae, as all taxa with available data for this character (Saintpaulia, Streptocarpus, and Cyrtandra Forster \& Forster) possess a three-trace trilacunar node except 
Aeschynanthus, which has a one-trace trilacunar node common to the Gesnerioideae.

\section{PLACENTA}

The placenta in the Gesneriaceae is either intact or divided to the base (Ivanina, 1965). This character was included in a cladistic analysis of morphological data and served as a character state that brought the Episcieae, Beslerieae, and Napeantheae together in a single clade (Smith, 1996) as the only taxa sampled that had divided placentae. Although this character state is consistent with the relationship between the Napeantheae and Beslerieae, the character state is homoplastic between the Episcieae and Napeantheae/Beslerieae based on the data presented here (Fig. 4).

\section{STEM MODIFICATION}

Several members of the Gesneriaceae possess modifications of the stems (rhizomes and tubers), presumably as adaptations to periodic dry seasons (Wiehler, 1983). The presence of scaly rhizomes is found almost exclusively, and is widespread, within the Gloxinieae (Wiehler, 1983). Among the taxa sampled here, the presence of scaly rhizomes serves as a synapomorphy for the tribe Gloxinieae, although they are not known from the woody genus Solenophora. Scaly rhizomes also are known from the Cyrtandroideae, including Titanotrichum (Kao \& DeVol, 1972; Wang et al., 1992).

Tubers are widespread among species of Sinningia including Lietzia, which has recently been combined into Sinningia (Wiehler \& Chautems, 1995). Although tubers serve to unite these genera, and to separate them from the Gloxinieae, tubers are not known from Paliavana or Vanhouttea. However, not all species of Sinningia are tuberous, and the lack of tubers in these species can be regarded as intratribal or intra-generic variation. Tubers also are known from several species in the Episcieae (Drymonia, Chrysothemis Dene., Nautilocalyx Lind. ex Hanst., Paradrymonia Hanst., and Rhoogeton Leeuwenberg) as well as one member of the Gloxinieae (Lembocarpus Leeuwenberg). Further studies that include these taxa will hopefully resolve the number of times tubers have originated within the Gesneriaceae.

\section{BIOGEOGRAPHY}

The traditional division of the Gesneriaceae into two subfamilies (excluding the Klugieae, which may stand best as a third subfamily) is well supported in this analysis and is in agreement with the biogeographic distribution of these taxa. The Cyrtandroideae (excluding the Klugieae) are distributed almost exclusively in the paleotropics with a few temperate European and Asian species. Two African genera were included in this analysis, both of which are in a single clade (Saintpaulia and Streptocarpus). Only one of the European taxa (Ramonda L. C. Richard) has been included in this analysis; therefore nothing can be inferred regarding the origin of these taxa at this time.

Members of the tribe Klugieae range from India to south China, Taiwan, the Philippines through Malaysia, Indonesia, and into New Guinea. Discrepancies from this distribution include a single species of Rhynchoglossum Blume found in Central and South America. The presence of Rhynchoglossum azureum (Schlecht.) B. L. Burtt in the Neotropics represents a secondary dispersal event in the family, because all other members of the Klugieae are found in the Old World.

The Gesnerioideae are almost exclusively neotropical, but with the inclusion of the Coronanthereae within this subfamily the Gesnerioideae now encompass several Australian and South Pacific island species.

\section{Literature Cited}

Ackerman, J. D. 1986. Coping with the epiphytic existence: Pollination strategies. Selbyana 9: 52-60.

Bentham, G. 1876. Gesneriaceae. Pp. 990-1025 in G. Bentham \& J. D. Hooker (editors), Genera Plantarum. Lovell Reeve, London.

Boggan, J. K. 1991. A morphological study and cladistic analysis of Sinningia and associated genera with particular reference to Lembocarpus, Lietzia, Paliavana, and Vanhouttea (Gesneriaceae: Gloxinieae). M.S. Thesis, Cornell University, Ithaca, New York.

Bremer, K. 1988. The limits of amino acid sequence data in angiosperm phylogenetic reconstruction. Evolution 42: $795-803$.

. 1994. Branch support and tree stability. Cladistics 10: 295-304.

Burtt, B. L. 1962. Studies in the Gesneriaceae of the Old World XXIV: Tentative keys to the tribes and genera. Notes Roy. Bot. Gard. Edinburgh 24: 205-220.

- 1965. The transfer of Cyrtandromoea from Gesneriaceae to Scrophulariaceae, with notes on the classification of that family. Bull. Bot. Surv. India 7: 73-88.

1977. Classification above the genus, as exemplified by Gesneriaceae, with parallels from other groups. Pl. Syst. Evol., Supplement 1: 97-109.

\& H. Wiehler. 1995. Classification of the family Gesneriaceae. Gesneriana 1: 1-4.

Cantino, P. D. 1992. Evidence for a polyphyletic origin of the Labiatae. Ann. Missouri Bot. Gard. 79: 361-379.

Chase, M. W., D. E. Soltis, R. G. Olmstead, D. Morgan, D. H. Les, B. D. Mishler, M. R. Duvall, R. A. Price, H. G. Hills, Y.-L. Qiu, K. A. Kron, J. H. Rettig, E. Conti, J. D. Palmer, J. R. Manhart, K. J. Sytsma, H. J. Michaels, W. J. Kress, K. G. Karol, W. D. Clark, M. Hedrén, B. S. Gaut, R. K. Jansen, K.-J. Kim, C. F. 
Wimpee, J. F. Smith, G. R. Furnier, S. H. Strauss, Q.-Y. Xiang, G. M. Plunkett, P. S. Soltis, S. M. Swenson, S. E. Williams, P. A. Gadek, C. J. Quinn, L. E. Eguiarte, E, Golenberg, G. H. Learn, Jr, S. W. Graham, S. C. H. Barrett, S. Dayanandan \& V. A. Albert. 1993. Phylogenetics of seed plants: An analysis of nucleotide sequences from the plastid gene rbcL. Ann. Missouri Bot. Gard. 80: 528-580.

Clark, L. G., W. Zhang \& J. F. Wendel. 1995. A phylogeny of the grass family (Poaceae) based on $n d h \mathrm{~F}$ sequence data. Syst. Bot. 20: 436-460.

Crisci, J. V., M. M. Cigliano, J. J. Morrone \& S. RoigJuñent. 1991. Historical biogeography of southern South America. Syst. Zool. 40: 152-171.

Cronquist, A. 1981. An Integrated System of Classification of Flowering Plants. Columbia Univ. Press, New York.

Dahlgren, R. 1975. A system of classification of the angiosperms to be used to demonstrate the distribution of characters. Bot. Not. 128: 119-147.

Donoghue, M. J. \& P. D. Cantino. 1984. The logic and limitations of the outgroup substitution approach to cladistic analysis. Syst. Bot. 9: 192-202.

$\longrightarrow$, R. G. Olmstead, J. F. Smith \& J. D. Palmer. 1992. Phylogenetic relationships of Dipsacales based on rbcL sequences. Ann. Missouri Bot. Gard. 79: 333345.

Farris, S. J. 1970. Methods for computing Wagner trees. Syst. Zool. 19: 83-92.

, A. G. Kluge \& M. J. Eckardt. 1970. A numerical approach to phylogenetic systematics. Syst. Zool. 19: 172-191.

Fritsch, K. 1893-1894. Gesneriaceae. Pp. 133-185 in: A. Engler \& K. Prantl (editors), Die Naturlichen Pflanzenfamilien. Vol. 4(3b). Wilhelm Engelmann, Leipzig.

Heywood, V. H. 1978. Flowering Plants of the World. Prentice Hall, Englewood Cliffs, New Jersey.

Innis, M. A., K. B. Myambo, D. H. Gelfand \& M. A. D. Brow. 1988. DNA sequencing and direct sequencing of polymerase chain reaction-amplified DNA. Proe. Natl. Acad. Sci. U.S.A. 85: 9436-9440.

Ivanina, L. I. 1965. Application of the carpological method to the taxonomy of Gesneriaceae. Notes Roy. Bot. Gard. Edinburgh. 26: 383-402.

Judd, W. S., R. W. Sanders \& M. J. Donoghue. 1994. Angiosperm family pairs: Preliminary phylogenetic analyses. Harvard Pap. Bot. 5: 1-51.

Kao, M.-T. \& C. E. Devol. 1972. The Gesneriaceae of Taiwan. Taiwania 17: 142-169.

Kress, W. J. 1986. The systematic distribution of vascular epiphytes: An update. Selbyana 9: 2-22.

Kvist, L. P. 1990. Revision of Heppiella (Gesneriaceae). Syst. Bot. 15: 720-735.

Maddison, D. R. 1991. The discovery and importance of multiple islands of most-parsimonious trees. Syst. Zool. 40: $315-328$.

Maddison, W. P., M. J. Donoghue \& D. R. Maddison. 1984. Outgroup analysis and parsimony. Syst. Zool. 33: 83-103.

Madison, M. 1977. Vascular epiphytes: Their systematic occurrence and salient features. Selbyana 2 : 1-13.

Olmstead, R. G. \& J. D. Palmer. 1994. Chloroplast DNA systematics: A review of methods and data analysis. Amer. J. Bot. 81: 1205-1224.

\& P. A. Reeves. 1995. Evidence for the polyphyly of the Scrophulariaceae based on chloroplast rbcL. and ndhF sequences. Ann. Missouri Bot. Gard. 82: 176-193.
\& J. A. Sweere. 1994. Combining data in phylogenetic systematics: An empirical approach using three molecular data sets in the Solanaceae. Syst. Biol. 43: 467-481.

, B. Bremer, K. M. Scott \& J. D. Palmer. 1993. A parsimony analysis of the Asteridae sensu lato based on rbcL sequences. Ann. Missouri Bot. Gard. 80: $700-722$.

, H. J. Michaels, K. M. Scott \& J. D. Palmer. 1992. Monophyly of the Asteridae and identification of their major lineages inferred from DNA sequences of rbcL. Ann. Missouri Bot. Gard. 79: 249-265.

Scotland, R. W., J. A. Sweere, P. A. Reeves \& R. G. Olmstead. 1995. Higher level systematics of Acanthaceae determined by chloroplast DNA sequences. Amer. J. Bot. 82: 266-275.

Singh, V. \& D. K. Jain. 1978. Floral anatomy and systematic position of Cyrtandromoea. Proc. Natl. Acad. Sci. India 87: 71-74.

Skog, L. E. 1984. A review of chromosome numbers in the Gesneriaceae. Selbyana 7: 252-273.

1995. A possible realignment of Resia H. E. Moore (Gesneriaceae). Amer. J. Bot. 82: 161.

\& F. F. de Jesus. 1996. A review of Resia H. E. Moore (Gesneriaceae). Biollania (in press).

Smith, J. F. 1996. Tribal relationships within the Gesneriaceae: A cladistic analysis of morphological data. Syst. Bot. (in press).

\& K. J. Sytsma. 1994a. Evolution in the Andean epiphytic genus Columnea (Gesneriaceae): Part I. Morphological variation. Syst. Bot. 19: 220-235.

P $\&-1994 \mathrm{~b}$. Evolution in the Andean epiphytic genus Columnea (Gesneriaceae): Part II. Chloroplast DNA restriction site variation. Syst. Bot. 19: $317-336$.

- \& 1994c. Molecules and morphology: Congruence of data in Columnea (Gesneriaceae). PI. Syst. Evol. 194: 37-52.

K. D. Brown, C. L. Carroll \& D. S. Denton. 1997. Familial placement of Cyrtandromoea, Titanotrichum, and Sanango: Three problematic genera of the Lamiales. Taxon (in press).

, K. J. Sytsma. J. S. Shoemaker \& R. L. Smith. 1992. A qualitative comparison of total cellular DNA extraction protocols. Phytochem. Bull. 23: 2-9.

Sugiura, M. 1989. The chloroplast chromosomes in land plants. Ann. Rev, Cell Biol, 5: 51-70.

1992. The chloroplast genome. PI. Molec, Biol. 19: 149-168.

Swofford, D. L 1993. PAUP: Phylogenetic Analysis Using Parsimony, version 3.1.1 Computer program distributed by the Illinois Natural History Survey, Champaign, Illinois.

\& W. P. Maddison. 1987. Reconstructing ancestral character states under Wagner parsimony. Math. Biosci. 87: 199-229.

Takhtajan, A. L. 1980. Outline of a classification of flowering plants (Magnoliophyta). Bot. Rev. 46: 225-359.

Thorne, R. F. 1976. A phylogenetic elassification of the Angiospermae. Pp. 35-106 in M. K. Hecht, W. C. Steere \& B. Wallace (editors), Evolutionary Biology. Vol. 9. Plenum Press, New York.

1983. Proposed new realignments in the angiosperms. Nordic J. Bot, 3: 85-117.

- 1992. An updated phylogenetic classification of flowering plants (Magnoliophyta). Bot. Rev. (Lancaster) 46: $225-359$. 
Wang, W. T., K. Pan \& Z. Li. 1992. Keys to the Gesneriaceae of China. Edinburgh J. Bot. 49: 5-74.

Wiehler, H. 1983. A synopsis of the neotropical Gesneriaceae. Selbyana 6: 1-249.

\& A. Chautems. 1995. A reduction of Lietzia to Sinningia. Gesneriana 1: 5-7.
Wolfe, K. 1991. Protein-coding genes in chloroplast DNA: Compilation of nucleotide sequences, datahase entries and rates of molecular evolution. Pp. 467-482 in L. Bogorad \& I. K. Vasil (editors), The Photosynthetic Apparatus: Molecular Biology and Operation, vol. 7B, Cell Culture and Somatic Cell Genetics in Plants. Academic Press, New York. 